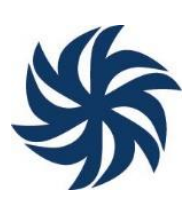

\title{
UNIÃO ESTÁVEL OU NAMORO QUALIFICADO?: UMA DIFERENCIAÇÃO NECESSÁRIA PARA A GARANTIA DA IMPOSIÇÃO ILEGÍTIMA DE DEVERES E ULTRAJE A DIREITOS
}

\author{
STABLE MARRIAGE OR QUALIFIED DATING?: A DIFFERENTIATION \\ NECESSARY TO GUARANTEE THE ILLEGITIMATE IMPOSITION OF DUTIES \\ AND OUTRAGE OF RIGHTS
}

\author{
¿MATRIMONIO ESTABLE O CITA CALIFICADA?: UNA DIFERENCIACIÓN \\ NECESARIA PARA GARANTIZAR LA IMPOSICIÓN ILEGÍTIMA DE DEBERES Y \\ LA VIOLACIÓN DE LOS DERECHOS.
}

\author{
Weverton Fernandes Bento Alves ${ }^{1}$ \\ Elza Maria Dias Vieira Costa ${ }^{2}$
}

\begin{abstract}
Resumo: Neste trabalho apresenta-se o avanço da concepção do entendimento de entidade familiar pela sociedade e pelo Estado brasileiro. À medida que, com as novas formas de uniões afetivas presentes na contemporaneidade, estas não devem, categoricamente e sob uma análise superficial, serem consideradas como família eminentemente constituída, sem observar os elementos caracterizadores de entidade familiar prescritos pelo ordenamento jurídico pátrio. Assim, demonstrar-se-á, utilizando-se do método da dogmática jurídica, dispondo, para tanto, da revisão doutrinária, da Metodologia de Análise de Decisões (MAD) e da revisão da legislação relacionados ao tema em questão, como plenamente válido, o reconhecimento da relação amorosa formada pelo namoro qualificado. Tal relação é entendida como uma forma de relacionamento face às várias formas de união afetiva no contexto brasileiro para que se garanta a vontade dos envolventes, de modo a salvaguardá-los da imposição ilegítima de deveres e da infringência de direitos.
\end{abstract}

Palavras-chave: Namoro qualificado; Uniões afetivas; União estável; Família.

Abstract: This paper presents the advance of the conception of the understanding of family entity by the society and by the Brazilian State. As, with the new forms of affective unions present in the contemporaneity, these should not, categorically and superficially, be considered as an eminently constituted family, without observing the characterizing elements of family entity prescribed by the national legal order. Thus, it will be demonstrated, using the method of dogmatic for this purpose, the Doctrinal Review, the Decision Analysis Methodology (MAD) and the review of the legislation related to the topic in question, as fully valid, the recognition of the relationship formed by qualified dating, as a perfect form of relationship various forms of affective unions in the Brazilian context to guarantee the real will of the surrounding, in order to safeguard them from the unlawful imposition of duties and infringement of rights.

Keywords: Qualified relationship; Affective unions; Stable union; Family.

\footnotetext{
${ }^{1}$ Mestrando em Economia Doméstica pela Universidade Federal de Viçosa (UFV). Especialista em Direito da Família pela Universidade Candido Mendes (UCAM). Bacharel em Direito pela Faculdade Mineira de Direito da Pontifícia Universidade Católica de Minas Gerais (PUC Minas). Mediador formado pela Escola Judicial Desembargador Edésio Fernandes (Ejef) do Tribunal de Justiça de Minas Gerais (TJMG). Advogado.

${ }_{2}$ Mestra em Direito Processual Civil e Bacharela em Direito pela Faculdade Mineira de Direito da Pontifícia Universidade Católica de Minas Gerais (PUC Minas). Professora Adjunta IV de Direito Civil da PUC Minas. Advogada.
} 
Resumen: Este trabajo presenta el avance de la comprensión de la comprensión de una entidad familiar por parte de la sociedad y del Estado brasileño. Como, con las nuevas formas de uniones afectivas presentes en los tiempos contemporáneos, no deberían, categóricamente y bajo un análisis superficial, ser consideradas como una familia eminentemente constituida, sin observar los elementos que caracterizan a una entidad familiar prescrita por el sistema legal nacional. Así, se demostrará, utilizando el método de la dogmática jurídica, teniendo, para ello, la revisión doctrinal, la Metodología de Análisis de Decisiones (MAD) y la revisión de la legislación relacionada con el tema en cuestión, como totalmente válida, El reconocimiento de la relación amorosa formada por citas calificadas, como una forma perfecta de relación frente a las diversas formas de uniones afectivas en el contexto brasileño, para garantizar la voluntad real de los involucrados, para salvaguardarlos de la imposición ilegítima de deberes e infracciones. de derechos.

Palabras clave: Citas calificadas; Uniones afectivas; Unión estable; Familia

\section{Introdução}

A pós-modernidade possibilitou a existência de inúmeras formas de uniões afetivas que, por seu turno, carecem de esclarecimento para verificar quando uma união afetiva se caracteriza enquanto entidade familiar devidamente constituída no presente. Isso porque se verifica que a contemporaneidade se vê marcada por diversas formas das pessoas se relacionarem afetivamente, saindo do entendimento tradicional do conceito de família, ou seja, aquela formada por casais heteroaferivos e seus filhos - família nuclear - e, consequentemente, englobando as mais variadas formas de uniões, sejam elas com objetivo de constituir família ou não.

Assim, as discussões acerca de uma relação amorosa ser considerada de forma categórica como entidade familiar já constituída e merecedora de total proteção do Estado especialmente do Direito de Família, mostra-se totalmente incoerente com os princípios constitucionais, em especial, os que dizem respeito a autonomia privada e da liberdade do ser humano. Haja vista que com a evolução da concepção das diversas formas de se relacionar afetivamente com outrem, tanto pelo ordenamento jurídico brasileiro, como pelo corpo social, as relações amorosas que, na sua superficialidade, assemelham-se a família constituída pela união estável, carecem de uma análise minuciosa dos elementos caracterizadores da referida união para que se possa sustentar que não é qualquer trato afetivo que deve ser considerado como família eminentemente constituída, sob pena de imposição ilegítima de deveres e ultraje a direitos.

Com efeito, apresenta-se o namoro qualificado como resposta aos paradigmas familiares. À medida que para dirimir os equívocos mencionados, nas próximas páginas, utilizando-se do método da dogmática jurídica, dispondo, para tanto, da revisão doutrinária e da revisão da legislação relacionados ao tema em questão, analisar-se-á a transfiguração histórica do conceito de família e, na sequência, a entidade familiar formada pela união estável, para sustentar o reconhecimento desta nova modalidade de união afetiva no ordenamento jurídico brasileiro. 
Utilizar-se-á, ainda, da Metodologia de Análise de Decisões (MAD) ${ }^{3}$ a fim de reconstruir os argumentos adotados pelos ministros do Superior Tribunal de Justiça (STJ) para a diferenciação da união estável do namoro qualificado no julgamento do Recurso Especial (REsp) no 1.454.643 - RJ (2014/0067781-5), em que se analisou a comunicação ou não de bens de um casal em um procedimento de reconhecimento e dissolução de união estável cumulado com partilha de bens

\section{O Percurso Histórico para a Compreensão da Família Contemporânea}

O entendimento contemporâneo do conceito de família mostra-se totalmente adverso a sua gênese, de modo que tanto o corpo social como o ordenamento jurídico brasileiro consideram como entidade familiar as mais variadas formas de relações afetivas. Assim, para que se possa compreender a atual caracterização de família enquanto entidade familiar devidamente construída e suas variações, faz-se indispensável analisar, mesmo que sumariamente, os marcos substanciais de sua transformação.

\subsection{A família no Direito Romano e no Direito Canônico}

A origem do modelo de família brasileiro adveio da concepção romana do referido instituto, sistematizado em normas severas que fizeram da família uma sociedade patriarcal. A família na Roma Antiga se organizava, hegemonicamente, no poder e na posição do pai, pessoa sui júris ${ }^{4}$ e com caráter unitário e absoluto na chefia de toda família que vivia sobre seu comando, o que foi denominado de pátrio poder (COULANGES, 2007, grifo nosso).

Nesse seguimento, para Wald (2002, p. 9, grifo nosso), a família era, ao mesmo tempo,

[...] uma unidade econômica, religiosa, política e jurisdicional. Inicialmente, havia um patrimônio só que pertencia à família, embora administrado pelo pater. Numa fase mais evoluída do direito romano, surgiam patrimônios individuais, como os pecúlios, administrados por pessoas que estavam sob a autoridade do pater. (WALD, 2002, p. 9, grifo nosso),

Vislumbra-se, por conseguinte, que a família romana, conceituada como família natural, consistia, na verdade, em um núcleo de parentesco com finalidade precípua de administração de patrimônio sob subordinação do pai - em regra - ou do ascendente comum vivo mais velho, o qual exercia seu poder sobre os seus descendentes não emancipados, sua esposa e com as mulheres casadas com seus descendentes (COULANGES, 2007, grifo nosso).

A partir do século V, o Direito Canônico, marcado pelo Cristianismo e regulamentado pela Igreja Católica, considerava como família somente as relações decorrentes de cerimônias religiosas, julgadas como "sagradas" por esse ordenamento e, por isso, sua dissolução ocorria

\footnotetext{
${ }^{3}$ Método específico do Direito pelo qual se aprecia uma decisão judicial (FREITAS FILHO; LIMA, 2010).

${ }^{4}$ Senhor do seu Direito (COULANGES, 2007).
} 
exclusivamente com a morte de um dos consortes, por entender que o homem não podia dissolver uma união formada por Deus (WALD, 2002).

Com isso, depreende-se, em conformidade com regramento Canônico, que a Igreja desempenhava papel peculiar, à medida que suas decisões assumiam alta relevância para as decisões jurídicas e sociais sobre a família e, por isso, a Igreja começou a ter poderes para interferir de forma decisiva nos desígnios familiares (RUSSO, 2005).

Malgrado a interferência intensa da Igreja sobre os indivíduos, deve ser considerado um relativo avanço em direitos se compararmos com os ditames do Direito Romano, vez que que as mulheres deixaram de ser tão dependentes dos homens e se tornaram uma parte importante para instituição da família. Todavia, elas ainda não representavam grandes forças em relação a questão do sacramento, mas, em contrapartida, competia-lhes deveres e direitos conjugais (RUSSO, 2005).

Dito isto, o casamento cristão e a Igreja ditaram os padrões do ideal de uma família normal para à época, que seria meramente a união afetiva formada pelo casamento como única conduta aceita, evidenciando que as relações sofriam influência direta dos detentores da ordem corrente e eram amargadas pelas exigências destes.

\subsection{A Família no Direito Brasileiro antes da Promulgação da Constituição Federal de 1988}

Em razão da colonização pelos portugueses, o Brasil se fundou de acordo com os preceitos da Igreja Católica Apostólica Romana, o que refletia diretamente no direito vigente à época, normatizado pelas Ordenações Filipinas, que reconhecia como entidade familiar apenas a união entre homem e mulher pelo casamento, que poderia ocorrer de forma solene, quando realizado na Igreja Católica, não se reconhecendo os realizados em religiões diversas; ou pelo trato público e da fama, conhecido como casamento com marido conhecido, ao passo que ambos, independente da forma, deveriam respeitar os preceitos católicos, especialmente, os que diziam respeito a indissolubilidade (WALD, 2002).

Importante salientar que no Brasil, por um vasto tempo, "a Igreja Católica foi titular quase que absoluta dos direitos matrimoniais; pelo Decreto de 3 de novembro de 1827 os princípios do direito canônico regiam todo e qualquer ato nupcial, com base nas disposições do Concílio Tridentino e da Constituição do Arcebispado da Bahia” (DINIZ, 2008, p. 51). Ademais, o casamento como meio único de reconhecimento jurídico de entidade familiar no Brasil foi mantido pelas legislações imperiais, acrescentando também como válido, apenas o casamento civil em 1821 às outras uniões religiosas, sobre o qual também pairava a indissolubilidade (WALD, 2002).

Noutro giro, apenas em 1890, com a edição do Decreto $\mathrm{n}^{\circ} 181$ de autoria de Rui Barbosa, os preceitos canônicos foram flexibilizados e passou-se a admitir como único casamento válido aquele realizado pelas autoridades e possibilitou a separação de corpo, 
relativizando a indissolubilidade do matrimônio. Esse decreto manteve sua vigência até a promulgação do Código Civil de 1916 (Lei no 3.071/16), o qual preservou o patriarcalismo, incluindo a mulher casada no rol dos indivíduos relativamente incapazes, e consagrou, ainda, que apenas pelo casamento pode-se formar a família, intrincando, do mesmo modo, a adoção e o reconhecimento de filhos havidos fora do núcleo familiar estabelecido pelo casamento (WALD, 2002).

Da mesma forma, na ótica desse Código, projeto de Clóvis Beviláqua, a família foi considerada "como organização social essencial à base do sistema" (FACHIN, 2003, p. 12), à medida que o marido era o chefe da sociedade conjugal e tinha como dever prover a manutenção de toda a família, cabendo a mulher apenas colaborar com tal função. Cessando para o marido a obrigação de sustentar a mulher quando ela abandonava a habitação conjugal e se recusava a ele voltar (CAROSSI, 2003).

Além disso, o diploma civil de 1916 conferiu proteção demasiada ao casamento ao impossibilitar a dissolução do vínculo conjugal, permitindo, apenas em casos excepcionais, o denominado "desquite", de modo que "na restrita visão do Código Civil de 1916, a finalidade essencial da família era a continuidade" (FUGIE, 2002, p. 133).

Insta salientar que apenas em 1977, com a edição da Lei $\mathrm{n}^{\circ}$ 6.515, criou-se a possibilidade da separação judicial e, consequentemente, sua conversão em divórcio se atendidos requisitos como a prévia separação judicial por mais de cinco anos ou de comprovada separação de fato por mais de cinco anos consecutivos e a impossibilidade de sua reconstituição ${ }^{6}$, de acordo a redação original da norma.

Pode-se verificar, pelas preposições expostas, que durante décadas a legislação brasileira protegeu a todo custo a instituição da família e os laços sanguíneos entre os parentes, vedando ou criando empecilhos para a dissolução da relação conjugal, mantendo, a todo custo, a família como base da sociedade de forma impositiva.

Outrossim, todos as outras uniões afetivas, mesmo que apresentasse todos os elementos de um casamento, como a união estável, foram desprezadas pelo legislador de 1916, não assegurando nenhum direito a tais uniões, impondo, por óbvio, o matrimônio como único meio de se constituir família e tê-la protegida pelo Estado.

Nesse seguimento, relevante é o posicionamento de Dias (2004, p. 35) sobre o ultraje a liberdade do ser humano pelas determinações do Estado, qual seja:

\footnotetext{
${ }^{5}$ Ato jurídico pelo qual se dissolve a sociedade conjugal, com separação de corpos e bens dos cônjuges, sem quebra do vínculo matrimonial (DIAS, 2016).

${ }^{6}$ O lapso temporal a ser comprovado da prévia separação judicial, bem como o da separação de fato foi alterado, respectivamente, para 1 ano pela Lei $n^{\circ} 8.408 / 92$ e para 2 anos pela Lei $n^{\circ} 7.841 / 89$. E, apenas em 2010, com a promulgação da Emenda Constitucional n. ${ }^{\circ} 66$, tais requisitos para a dissolução do casamento foram suprimidos (DIAS, 2016).
} 
A negativa de reconhecer os filhos fora do casamento possuía nítida finalidade sancionatória, visando a impedir a procriação fora dos "sagrados laços do matrimônio". Igualmente afirmar a lei que o casamento era indissolúvel servia como verdadeira advertência aos cônjuges de que não se separassem. Também negar a existência de vínculos afetivos extramatrimoniais não almeja outro propósito senão o de inibir o surgimento de novas uniões. O desquite - estranha figura que rompia, mas não dissolvia o casamento - tentava manter a todos no seio das famílias originalmente constituídas. Desatendida a recomendação legal, mesmo assim era proibida a formação de outra família. (DIAS, 2004, p. 35).

No que diz respeito ao ordenamento constitucional, a Constituição Federal de 1934 foi precursora em atentar para a família, dedicando um capítulo a ela, a fim de garantir expressamente a proteção especial do Estado a esta instituição, preceitos estes, que foram repetidos pelas constituições subsequentes (LÔBO, 2009).

Em que pese a proteção constitucional dada a família, as Constituições que sobrevieram após a Constituição Federal de 1934 quase não alteraram as normas do Código Civil em discussão, mantendo com as mesmas características a concepção legal de família. Portanto, continuou seguindo a estrutura patriarcal; o casamento como forma exclusiva de formação da família; o expresso tratamento discriminatório dado aos filhos nascidos fora do casamento e aos havidos por adoção; e a ausência de referências ao companheirismo (LÔBO, 2009).

Com efeito, estes padrões instituídos do conceito de família passaram a ser relativizados, especialmente, por Leis infraconstitucionais, como a já citada Lei do Divórcio (lei $n^{\circ}$ 6.515/77), a Lei da Adoção (lei no 3.133/57), e o Estatuto da Mulher Casada (lei no 4.121/62), que devolveu a plena capacidade à mulher casada, demonstrando, claramente, supremacia do interesse político-estatal sobre o anseio do ser humano em ter plena autonomia privada (DIAS, 2016).

Portanto, frente os argumentos apresentados, percebe-se que antes da promulgação da Constituição da República de 1988, as mudanças ocorridas nos ordenamentos constitucionais e nas legislações infraconstitucionais, não inovaram o conceito de família, reconhecendo este instituto apenas com a celebração do matrimônio, ignorando quaisquer outras formas de relação que não se enquadrava no sistema normativo vigente, e, além disso, igualmente não se preocupou o legislador em vedar a discriminação entre os filhos consanguíneos e os adotados, conservando, por seu turno, a imperatividade do ideal estatal sobre a realidade vivenciada pelos indivíduos.

\subsection{A Família na Constituição da República Federativa de 1988 e no Código Civil de 2002}

Com a promulgação da Constituição da República Federativa do Brasil, aos 05 dias de outubro de 1988, conhecida com Constituição Cidadão, a família passa a ter novos contornos, consignados em princípios e direitos conquistados pela sociedade, contrapondo o modelo autoritário e patriarcal prescrito pelo Código Civil de 1916. Dessa forma, consoante o novo 
texto constitucional, a família assume perspectivas diversas, fundada em preceitos como a igualdade, solidariedade e do respeito à dignidade da pessoa humana, que devem ser entendidos como fundamentos e também como objetivos do Estado brasileiro (LÔBO, 2009).

À vista disso, o entendimento pelo qual a família era considerada apenas a relação de matrimônio entre homem e mulher, supera-se e, em contrapartida, novas formas de relacionamento são assimilados, pois que a união estável entre o homem e a mulher, bem como a comunidade formada por qualquer dos pais e seus descendentes (família monoparental) constituem-se como entidade familiar.

Nesse respeito, Gomes (2002, p. 34, grifo nosso) em sua obra de Direito de Família, dispõe que

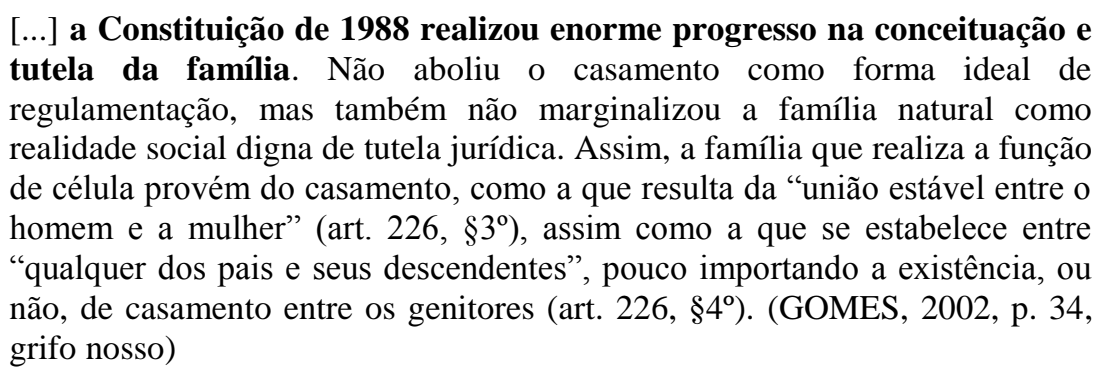

Por esses argumentos, verifica-se que com advento da Constituição de 1988, os preceitos arraigados e, sobremaneira, demasiados sobre o juízo do que se compreende como família, foram mitigados e, como consequência direta, a discriminação insculpida pelo tradicionalismo patriarcal amparado pelo Código Civil à época vigente teve que segregar-se para que a dignidade da pessoa humana, princípio base do Estado Democrático de Direito, satisfizesse os anseios sociais em busca da igualdade.

Confirmando o preceito de igualdade trazido pela Constituição foram editadas Leis que viabilizassem tal paridade, como a Lei $\mathrm{n}^{\circ} 8.971$ de 1994, que estabeleceu o direito dos companheiros a alimentos e a sucessão; a Lei no 9.278 de 1996, que regulou o artigo $226, \S 3^{\circ}$ da Constituição Federal, que trata da união estável, de jeito a se garantir às relações formadas sem o ato solene do casamento os direitos assegurados pelo texto constitucional (DIAS, 2016).

Com efeito, as diretrizes constitucionais que dizem respeito à família introduzidas pelo novo texto constitucional só foram instituídas pela legislação infraconstitucional com a publicação da Lei $n^{\circ} 10.406$ de 10 janeiro de 2002, o atual Código Civil (BRASIL, 2002), razão pela qual se exigia uma interpretação Civil-Constitucional, devida ao lapso temporal de 14 (quatorze) anos da promulgação da Constituição e o advento do novo ordenamento civil.

Desta feita, com a publicação do novo Código Civil, pode-se inferir que a referida codificação, em verdade, não apresentou inovação, vez que apenas evidenciou as disposições já estabelecidas pelo texto magno de 1988 (DIAS, 2017). 
A respeito da importância das inovações, ora codificadas, Leite (2008), diz ser

[...] aquela que diz respeito à isonomia conjugal, consagrando que pelo casamento homem e mulher assumem mutuamente a condição de consortes, ou companheiros, e são responsáveis pelos encargos da família (a saber: a fidelidade recíproca, a vida em comum no domicílio conjugal ou more uxório, a mútua assistência e o sustento, guarda e educação dos filhos, com o acréscimo do respeito e consideração mútuos. (LEITE, 2008).

Isto posto, percebe-se que a família que, em sua origem, guardava respeito primordial com a manutenção do patrimônio e com a indissolubilidade conjugal, torna-se fundamental para o desenvolvimento do indivíduo, não para o desenvolvimento da prole ou do Estado, corroborando com o argumento de que o Estado deve salvaguardar as exigências da coletividade e, acima de tudo, adequar-se à realidade vivenciada pelos indivíduos em sociedade.

\subsection{A Família do Ponto de Vista Contemporâneo}

Em linhas gerais, ao considerarmos o contexto histórico, a liberdade do indivíduo em se relacionar afetivamente conduziu-se por questões de indissolubilidade, desigualdade de direitos decorrentes do sexo, discriminação da prole em função de sua origem, impossibilidade e/ou dificuldade em se dissolver uma relação conjugal existente e por hostilidade aos relacionamentos dissonantes do ordenamento vigente, os quais não eram considerados e, até mesmo, censurados (DIAS, 2016).

No entanto, a contemporaneidade se vê marcada por diversas formas de se relacionar, saindo do entendimento tradicional do conceito de família e englobando as mais variadas formas de uniões afetivas, com ou sem o objetivo presente de constituir família (DIAS, 2016). Pois que o Censo de 2010 do Instituto Brasileiro de Geografia e Estatística (IBGE) ao fazer a análise sobre a família concluiu, conforme dados abaixo transcritos, que:

[...] a compreensão do conceito tradicional de família, esteve presente em 49,9\% dos lares visitados, enquanto que em $50,1 \%$ das vezes, a família ganhou uma nova forma. As famílias homoafetivas já somam 60 mil, sendo $53,8 \%$ delas formada por mulheres. Mulheres que vivem sozinhas são 3,4 milhões, enquanto que 10,1 milhões de famílias são formadas por mães ou pais solteiros (IBGE, 2010).

Ainda sobre o Censo de 2010, ressalta-se que este considerou como família o "conjunto de pessoas ligadas por laços de parentesco, dependência doméstica ou normas de convivência, residente na mesma unidade domiciliar, ou pessoa que mora só em uma unidade domiciliar" (IBGE, 2010).

Nesse respeito, Maria Berenice Dias (2016, p. 43) preleciona que a família contemporânea "[...] existe e contribui tanto para o desenvolvimento da personalidade de seus integrantes como para o crescimento e formação da própria sociedade, justificando, com isso, a sua proteção pelo Estado".

Da mesma forma, Farias; Rosenvald (2017, p. 37) atestam que: 
Ao colocar em xeque a estrutura familiar tradicional, a contemporaneidade (em meio a inúmeras novidades tecnológicas, científicas e culturais) permitiu entender a família como uma organização subjetiva fundamental para a construção individual da felicidade. E, nesse passo, forçoso é reconhecer que, além da família tradicional, fundada no casamento, outros arranjos familiares cumprem a função que a sociedade contemporânea destinou à família: entidade de transmissão de cultura e formação da pessoa humana digna. (FARIAS; ROSENVALD, 2017, p. 37).

Assim, a concepção tida por muito tempo de que família era o núcleo formado por duas pessoas de sexo diferente e seus eventuais filhos mostra-se superada, ao passo que, hodiernamente, as pessoas além de constituir família das mais variadas maneiras, têm se relacionado de forma similar, mas não hegemônica, ao que se entende como família. Isso porque é notável que a sociedade brasileira não se organiza apenas em torno do casamento tradicional, pois ampliou-se o conceito de família e o Estado passou a reconhecer a existência de várias formas de união afetiva como entidades familiares (GOMES, 2009).

Portanto, esse conjunto de ideias apresentadas carece de ser observado no caso concreto de um relacionamento afetivo para que verifique se a união realmente tem por objetivo a constituição de família, pois, caso isso seja negligenciado, da mesma forma que a liberdade em se instituir uma relação foi, por muito tempo, impositiva, o mesmo ocorrerá caso o Estado compulse a caracterização taxativa como entidade familiar, sem observar o liame subjetivo daqueles que se relacionam e desrespeite, continuadamente, a vontade do indivíduo.

\section{A União Estável Como Uma das Várias Formas de se Relacionar na Contemporaneidade}

Hodiernamente, pondera-se que a concepção de família ostenta tanto pelo ordenamento jurídico pátrio, bem como pelo corpo social brasileiro, uma visão mais ampla, à medida que as mais variadas formas de ralações afetivas podem ser consideradas como núcleo familiar (DIAS, 2016).

Nesse interim, em que os indivíduos, em regra, possuem liberalidade para se relacionar, seja em consonância com as regras legais que disciplinam a questão ou de acordo com seu próprio entendimento subjetivo sobre relacionar-se, muitas formas de se constituir um núcleo familiar e, consequentemente, ter reconhecida tal relação como família, insurge a problemática em ter qualquer relação afetiva entre duas pessoas considerara categoricamente como entidade familiar (MALUF; MALUF, 2013).

Isto pois, com o entendimento atual da sociedade sobre os novos modelos de dois indivíduos constituírem família, doravante ratificado pela hermenêutica do Poder Judiciário (BRASIL, 2015a), essas variadas formas de se relacionar que são conceituadas como família não devem, de plano, serem caraterizadas como entidade familiar, de modo a recair todos os efeitos legais sobre aqueles que se relacionam, muitas vezes, de maneira similar a uma família 
constituída, mas que, no caso concreto não correspondem a tal compreensão (MALUF; MALUF, 2013).

Assim, em que pese a existências das mais variadas formas de se constituir um núcleo familiar e a importância ímpar de cada um deles, este trabalho explorará as minúcias da entidade familiar formada pela união estável para que se possa demonstrar as variáveis desse instituto no caso concreto, com o propósito de se sustentar que seus elementos constitutivos na contemporaneidade não devem ser impostos taxativamente a qualquer relação afetiva, sob pena de infringência de direitos e imposição ilegítima de deveres.

\subsection{A União Estável no Ordenamento Jurídico Brasileiro}

O artigo 226 da Constituição Federal equiparou a união estável entre homem e mulher ao casamento, dispondo em seu parágrafo $3^{\circ}$ que “[...] é reconhecida a união estável entre o homem e a mulher, como entidade familiar, devendo a lei facilitar sua conversão em casamento" (BRASIL, 1988), e no parágrafo $4^{\circ}$, preceitua que “[...] entende-se, também, como entidade familiar a comunidade formada por qualquer dos pais e seus descendentes" (BRASIL, 1988).

O Código Civil de 2002, no artigo 1.723, estabelece os requisitos fundamentais para a constituição da união estável, de modo que prescreve que "[...] é reconhecida como entidade familiar a união estável entre o homem e a mulher, configurada na convivência pública, contínua e duradoura e estabelecida com o objetivo de constituição de família (BRASIL, 2002).

Da mesma forma, o referido código disciplina no artigo 1.790, os efeitos patrimoniais das uniões estáveis pela morte de um dos companheiros, especificamente, sobre a forma de participação da sucessão do outro. Garantindo, nessa lógica, o direito à herança quando constituem família nessa modalidade, nos bens adquiridos onerosamente na constância da união (BRASIL, 2002).

À vista disso, verifica-se que a Lei Civil vigente, diferentemente das outras normas que a antecederam, reconhece expressamente a união estável e, além disso, disciplina as consequências sucessórias que dizem respeito ao patrimônio daqueles que se relacionam e constituem família em conformidade com o instituto familiar em estudo (DIAS, 2016).

Ao passo que prescreve, em linhas gerais, para a caracterização da união estável a existência demonstrada de maneira imprescindível dos seguintes elementos: I) convivência pública; II) contínua; III) duradoura; e IV) estabelecida com objetivo de constituir família, sendo os três primeiros elementos objetivos para a constituição da família formada pela união estável, e o último, o elemento subjetivo para a configuração e reconhecimento da referida entidade familiar. 
No que diz respeito ao patrimônio constituídos pelos companheiros, o art. 1.725 do Código Civil dispõe que "[...] na união estável, salvo contrato escrito entre os companheiros, aplica-se às relações patrimoniais, no que couber, o regime de comunhão parcial de bens" (BRASIL, 2002, grifo nosso), e ressalta que nos casos de união estável entre pessoas maiores de 60 (sessenta) anos, o regime a ser aplicado é o da separação obrigatória de bens, admitindo como exceção a aplicabilidade da Súmula n. ${ }^{\circ} 377$ do Supremo Tribunal Federal, que dispõe sobre a comunicação dos bens adquiridos onerosamente na constância da união, em face da presunção do esforço comum (BRASIL, 1964).

Após a discriminação genérica da união estável consoante a redação adstrita ao Código Civil de 2002, importante mencionar os avanços da entidade familiar em discussão sobre a igualdade de sexos e o recente entendimento jurisprudencial acerca da participação do companheiro na sucessão. Dado que, de acordo com a literalidade do diploma civil, entende-se como entidade familiar apenas as relações formadas por homem e mulher, não se reconhecendo a possibilidade de relações homoafetivas e, por isso, coube a jurisprudência, a extensão da aplicação da lei a essas relações.

Destarte, o reconhecimento da união estável constituída por indivíduos do mesmo sexo, decorreu do julgamento da Ação Direta de Inconstitucionalidade (ADI) de n. ${ }^{\circ} 4.277$ e da Arguição de Descumprimento de Preceito Fundamental (ADPF) n. ${ }^{\circ} 132$ pelo Superior Tribunal Federal (STF), que ao julgar procedentes os pedidos desses pleitos, suprimiu esta situação pareando as relações homoafetivas com as heteroafetivas, afirmando o entendimento pelo qual também podem se casar ou constituir união estável pessoas do mesmo sexo (BRASIL, 2011).

De maneira similar, coube, também, ao STF afastar a discriminação contida no artigo 1.970 do Código Civil que estabelece diferenças entre a participação do companheiro e do cônjuge na sucessão dos bens com o julgamento recente dos Recursos Extraordinários (RE) 646721 e 878694, ambos com repercussão geral, em maio de 2017, declarando a inconstitucionalidade do referido dispositivo e equiparando os direitos entre cônjuge e companheiro para fins de sucessão, inclusive em uniões homoafetivas (BRASIL, 2017).

Consoante a Suprema Corte, tendo em vista a repercussão geral conferida ao julgado, deverá ser aplicada a todos os processos o entendimento pelo qual “[...] no sistema constitucional vigente é inconstitucional a diferenciação de regime sucessório entre cônjuges e companheiros devendo ser aplicado em ambos os casos o regime estabelecido no artigo 1829 do Código Civil” (BRASIL, 2017).

Levando-se em conta o que foi demonstrado, constata-se uma progressão do conceito de família e, em especial, sobre a entidade familiar formada pela união estável, confirmando a mutação eminente das formas de se relacionar e também que o Estado na sua função de regulamentador deve se ater a realidade dos indivíduos na vida em sociedade. 
Por conseguinte, para a análise do objeto do trabalho em tela, deve-se estudar como se concretiza uma relação como união estável em entidade familiar, haja vista a existências das relações que se assemelham a este instituto, bem como examinar seus elementos caracterizadores, que consistem na convivência entre duas pessoas - independentemente do sexo -, de forma pública, contínua, duradoura e com o objetivo presente de se constituir família.

\subsection{A Constituição da União Estável}

Tanto a Constituição Federal de 1988, como Lei Civil de 2002 não prescreveram uma forma solene para a caracterização da união estável, de modo que tal entidade familiar, mesmo dispensada das exigências legais como ocorre no casamento, consubstancia-se como família e merece total proteção do Estado (DIAS, 2016).

Nessa mesma ótica, Patrícia Fontanella, citada por Farias e Rosenvald (2017, p. 472), pondera que "[...] o legislador optou por evitar rigorismos conceituais, pois ao abster-se de conceituar rigidamente a união estável, deixou para o juiz - diante de cada caso concreto - a tarefa de analisa-la e reconhece-la ou não".

Assim sendo, a união estável consiste em uma situação de fato existente entre duas pessoas e desimpedidas de contrair matrimônio, que compartilham suas vidas, como se casadas fossem, o que se denomina de convivência more uxório ${ }^{7}$, o que não se confunde de forma alguma com o namoro, independentemente de sua intensidade (FARIAS; ROSENVALD, 2017, grifo nosso). Razão pela qual se pode afirmar que a referida relação amorosa consiste em “[...] um casamento de fato, [...] merecedor de especial proteção do Estado, uma vez que se trata de fenômeno social natural, decorrente da própria liberdade de autodeterminação de uma pessoa livre que opta por viver uma união livre" (FARIAS; ROSENVALD, 2017, p. 472).

Dito isto, verifica-se que para a constituição da união estável os conviventes não carecem de solenidades legais para sua formação e, consequentemente, ser considerada como entidade familiar. Devendo, por seu turno, apenas respeitar as regras de impedimento para o casamento disciplinadas pelo Código Civil para sua instituição, ao passo que caso isso ocorra, essa união pode ser considerada como concubinato ou como uma sociedade de fato, de jeito que tais institutos serão regulados pelas regras de direito obrigacional e deverá ser comprovado o esforço comum entre os que se envolvem para eventual partilha de patrimônio (DINIZ, 2008, grifo nosso).

No entanto, malgrado o legislador não exigir forma específica para instituição da união estável como entidade familiar, não se pode compreender como tal qualquer relação, à medida que se deve, no caso concreto, existir os elementos caracterizadores da referida forma de convivência de maneira induvidosa. Por isso, muitos casais que vivem nesta situação de fato

\footnotetext{
${ }^{7}$ Convivência como marido e mulher (DIAS, 2016).
} 
optam por fazer uma declaração, por instrumento público ou particular, da existência da união estável. De sorte que muitos companheiros utilizam desta forma para - genericamente e principalmente - definir qual o regime de bens que incidirá sobre sua entidade familiar, pois, como já foi mencionado, consoante a disciplina Civil, aplica-se a esta união, na inexistência de contrato estabelecido pelos conviventes, o regime de comunhão parcial de bens.

Da mesma forma, importante frisar que a declaração acima discriminada é utilizada também como um dos meios de prova judicial para demonstração da união entre os conviventes quando da dissolução da união estável ou como artifício para comprovação de direitos decorrente da sucessão, bem como para habilitar-se como dependentes junto a previdência social, inclusão em plano de saúde e seguro de vida (DINIZ, 2008).

Nesse mesmo seguimento, faz peculiar anotar que a declaração feita pelos companheiros, seja ela pública ou privada, não altera o estado civil dos que se relacionam sob esta forma de entidade familiar, mantendo, por conseguinte, o estado de solteiro, diferentemente do que ocorre quando da união formada pelo casamento (DIAS, 2016).

Denota-se, pelo exposto, que a entidade familiar formada pela união estável, de acordo com o ordenamento jurídico pátrio não requer forma solene como ocorre no casamento para sua constituição, de modo que por ser uma situação de fato, cabe aos conviventes a comprovação meticulosa dos elementos caracterizadores dessa união.

A referida comprovação, além da declaração já mencionada, tem sido feita pelos conviventes quando levada para apreciação do judiciário com base no Decreto 3.048 de 06 de maio de $1999^{8}$, alterado pelo Decreto $n^{\circ} 4.079$ de 9 de janeiro de 2002 que regulamenta as leis previdenciárias, que amparou-se por 06 anos na Resolução n. ${ }^{\circ} 40$ de 14 de agosto de 2007 do Concelho Nacional de Justiça (CNJ) que prescrevia, até a sua revogação em 2013 pela Resolução n. 167 de 07 de janeiro de 2013 também do CNJ (BRASIL, 2013), em seu artigo 2ª a apresentação de três documentos do aludido decreto (BRASIL, 2007).

Em função disso, os conviventes se valiam e equivocadamente ainda se valem (DIAS, 2016) da norma acima na parte que regulamenta a forma de comprovação da união estável para efeito de definição do companheiro (a), a ser incluído como dependente do segurado, assunto tratado pelo artigo 16 da Lei $\mathrm{n}^{\circ} 8.213$ de 24 de julho de 1991, que exige do dependente a apresentação de três documentos dentro de um rol exemplificativo previsto no parágrafo terceiro do artigo 22 para a comprovação da condição de companheiro (BRASIL, 1991).

Consoante a norma supramencionada, os documentos que servem como prova para delinear a existência da união estável e, por conseguinte, configurar o vínculo de dependência perante a Previdência Social, dentre outros, consistem em: certidão de nascimento de filho

\footnotetext{
${ }^{8}$ BRASIL. Decreto n. ${ }^{\circ} 3.048$ de 6 de maio de 1999. Aprova o Regulamento da Previdência Social, e dá outras providências. Diário Oficial da União, Brasília 6 maio 1999.
} 
havido em comum; certidão de casamento religioso; disposições testamentárias; declaração especial feita perante tabelião; prova de mesmo domicílio (BRASIL, 1991).

No entanto, tal exigência é considerada ilegal pelo Superior Tribunal de Justiça (STJ) e pela Turma Nacional de Uniformização dos Juizados Especiais Federais (TNU), uma vez que nem a Lei Previdenciária nem a Lei Civil exigem que a união estável seja comprovada por meio de documentos, sendo assim, essa formalidade não poderia ter sido instituída pelo decreto regulamentador (KERTZMAN, 2017).

Não bastasse a inexigibilidade e a inexistência na ordem Constitucional e no diploma Civil sobre declarações que evidenciam a comprovação da entidade familiar em estudo, importante frisar que os documentos supramencionados para comprovação de vínculo de dependência junto a Previdência Social, são disciplinados por meio de ato do Poder Executivo (BRASIL, 1999).

Por isso, de acordo com o inciso IV do artigo 84 da Constituição Federal de 1988, esta espécie normativa, enquanto competência privativa do Presidente da República, ocupa-se em "sancionar, promulgar e fazer publicar as leis, bem como expedir decretos e regulamentos para sua fiel execução" (BRASIL,1988), de jeito que por essa norma não se pode instituir ou modificar conteúdo de Lei, estando-a presa ao texto legal inarredavelmente.

Corroborando com esse ponto de vista, faz-se elementar transcrever o posicionamento de Ráo (1976, p. 269, grifo nosso) pelo qual menciona que

\footnotetext{
[...] o Poder Executivo ao exercer a função regulamentar não deve: criar direitos ou obrigações novas, que a lei não criou; ampliar, restringir ou modificar direitos ou obrigações constantes da lei; ordenar ou proibir o que a lei não ordena ou não proíbe; facultar ou vedar de modo diverso do estabelecido em lei; extinguir ou anular direitos ou obrigações que a lei conferiu; criar princípios novos, diversos, alterar a forma que, segundo a lei deve revestir um ato, atingindo por qualquer modo o espírito da lei. (RÁO, 1976, p. 269, grifo nosso).
}

Nesse seguimento, reafirmando que a comprovação da união estável depende, tão somente, da comprovação precisa de seus elementos constitutivos, o TNU consolidou posicionamento através da Súmula de $n^{\circ}$ 63, publicada em 23 de agosto de 2012, afirmando que “[...] a comprovação de união estável para efeito de concessão de pensão por morte prescinde de início de prova material" (BRASIL, 2012).

Razão pela qual se infere que o ordenamento jurídico nacional não prevê de maneira específica para a união estável um rol taxativo e/ou exemplificativo para se comprovar a constituição da entidade familiar em estudo. Motivo pelo qual cabe ao magistrado se atentar fielmente aos elementos constitutivos dessa união, de acordo com a previsão instituída pelo ordenamento Constitucional e Civil, principalmente quanto aos elementos subjetivos da entidade familiar em questão. 
Em vista disso, os elementos que caracterizam a entidade familiar em estudo devem, obrigatoriamente, serem confirmados pelos conviventes, haja vista que como essa confirmação é, na generalidade, a única exigência legal, não se pode negligenciar de forma alguma sobre eles sob pena de infringência de deveres. Que ora são conferidos de forma equivocada, ora são mitigados quando da superficialidade da veracidade dos referidos elementos (MALUF; MALUF, 2013).

Além de que, tendo em vista as várias formas de se relacionar presentes na contemporaneidade, muitas relações afetivas podem se apresentar na superficialidade, como entidade familiar, mas, na sua essência, não correspondem a uma família constituída e sim como uma mera projeção de consubstanciá-la no futuro (BRASIL, 2015a).

Portanto, cabe ao Estado, principalmente através do Poder Judiciário, na análise sistematizada de cada núcleo familiar levada para reconhecimento em Juízo, observar se existe ou não a união estável declarada pelos conviventes, pois, sendo-o garantidor do aplicação da norma subjetiva ao indivíduo, o descaso por uma verificação superficial culminaria com a mesma imposição estatal que se manteve presente por toda história da família, só que agora, a imposição se daria pelo desrespeito a real vontade daqueles que se relacionam afetivamente.

\section{Namoro Qualificado: Análise Crítica de Uma Nova Modalidade de Relação Afetiva}

Pode-se afirmar que o entendimento de família está em constante alteração (IBGE, 2010). Ao passo que também se pode depreender que o Estado sempre interviu diretamente nessa instituição de maneira demasiada, muitas vezes cerceando a liberdade do indivíduo em se relacionar com outrem, outras vezes disciplinando de forma impositiva sua formalização (LÔBO, 2009).

Consequentemente, considerando o entendimento da sociedade sobre a união entre duas pessoas, que hodiernamente se organizam de diversas formas, importante demonstrar que o Estado não deve conclusivamente e a seu bel prazer, definir como se concretiza uma união como entidade familiar, principalmente em razão dos princípios constitucionais da liberdade e da autonomia da vontade do ser humano (DIAS, 2016).

À vista disso, é necessário examinar caso a caso as peculiaridades das uniões afetivas presentes no contexto brasileiro. Pois, sabido que hoje a família não se constitui apenas pelo seu conceito arcaico de uma união entre homem e mulher e seus filhos, muitas uniões, por mais semelhanças que apresentam com uma entidade familiar formada, em seu âmago não condizem com a consolidação eminente da referida instituição (BRASIL, 2015a).

Assim, tomando por base a família formada pela união estável, passar-se-á a demonstrar que não se deve definir prontamente qualquer relação amorosa como família pela mera superficialidade das semelhanças existentes nas formas de se relacionar. As quais carecem de 
uma avaliação pormenorizada de seus elementos constitutivos para que se possa sustentar sua existência ou não como entidade familiar já constituída.

\subsection{A Compreensão do Namoro Qualificado}

Como já foi mencionado, no momento atual, as várias formas de relacionamento afetivo tem sido alvo de grandes discussões acerca do conceito de família, tendo em vista as diversas variantes e concepções que dizem respeito às suas peculiaridades (DIAS, 2016).

Nesse sentido, a argumentação para o enquadramento de uma união afetiva em uma forma específica de família, torna-se papel aflitivo para os magistrados e doutrinadores. Razão pela qual a aludida questão não corrobora com a ideia de correlacionar o caso concreto a um rol taxativo de enquadramento familiar, delimitando e formulando o abarcamento da vida pessoal em uma dogmática exata (DIAS, 2016).

Isto porque a nova perspectiva do Direito de Família "Civil-Constitucional" engloba valores e princípios mais abrangentes, alcançando direitos fundamentais, como a dignidade da pessoa humana (artigo $1^{\circ}$, III, da CF); a solidariedade social (artigo $3^{\circ}$, I da CF); e a afetividade que, nesse contexto, ganha dimensão jurídica; isonomia, ao reafirmar a igualdade de direitos e deveres do homem e da mulher e o tratamento jurídico igualitário dos filhos (artigo $5^{\circ}$, I da CF). (BRASIL, 1988).

Consequentemente, por ser a união estável uma situação de fato, livre de solenidades para sua formulação, como se verificou no capítulo anterior, muitos relacionamentos amorosos têm sido equivocadamente compreendidos com tal instituição familiar. Pois que diferentemente da união estável que é conceituada pela Lei, o namoro não se respalda em exigências na ordem normativa pátria. “Assim sendo, não há requisitos a serem observados para sua formação, a não ser os requisitos morais, impostos pela própria sociedade e pelos costumes" (MALUF; MALUF, 2016, p. 6).

Com efeito, amparados pelo costume e a moral, muitos relacionamentos amorosos, em especial, os que guardam um estreitamento afetivo maior, como o noivado, transmitem para o corpo social uma ideia similar de uma família constituída pela união estável (COSTA, 2007).

Ainda nesse respeito, a aparência desacertada do casal para a sociedade enquanto família, ampara-se na publicidade, fidelidade e uma possível intenção de casamento ou constituição de união estável no futuro demonstradas, mas que, diversamente da ideia transmita, os envolventes não estão em uma relação familiar consolidada (DIAS, 2016).

Sobre essa ambiguidade de entendimento, os autores Maluf; Maluf (2016, p. 7, grifo nosso) mencionam que 
[...] a confusão que pode surgir entre o namoro e a união estável ocorre nas relações em que há observância das regras morais impostas pela sociedade. São aqueles relacionamentos duradouros, com convivência contínua do casal, nos quais há fidelidade mútua, pelo menos na aparência, na qual ambos se apresentam na sociedade como namorados. (MALUF; MALUF, 2016, p. 7, grifo nosso).

Nessa sequência é que surge o denominado namoro qualificado como resposta alternativa à união estável, mantendo, por conseguinte, a liberdade individual dos que se relacionam, sobretudo, a imposição ilegítima de deveres decorrentes de uma viciada compreensão de uma relação entre duas pessoas como família constituída no presente (MALUF; MALUF, 2013, grifo nosso).

Isto pois, a despeito da já mencionada mudança da família brasileira que, atualmente, tem sido formada de maneira facultativa à regra estabelecida em Lei, uma relação entre duas pessoas, por mais similaridade que guarda com a compreensão contemporânea de família, não deve ser categoricamente enquadrada como tal, tendo em vista o ânimo de estabelece-la no futuro (DIAS, 2016).

Vislumbra-se a existência do namoro qualificado, de forma exemplifica, quando um casal, de maneira superficial, mostra-se como união estável e, por consequência, é tratado como família já constituída, acarretando a imposição ilegítima de deveres, em especial aos patrimoniais, por interpretá-las como se fossem iguais, quando na verdade, no caso específico, deve ser compreendida como a mera perspectiva de constituir família (BRASIL, 2015a).

Por essa premissa verifica-se que a família deve ser protegida pelo Estado, consoante o caput do artigo 226 da Lei Magna, que dispõe que "[...] a família, base da sociedade, tem especial proteção do Estado" (BRASIL, 1988), porém, da mesma forma, a concepção das relações interpessoais afetivas com finalidade futura de se constituir família merecem ser notadas (DIAS, 2016).

Assim, o namoro qualificado, carente de affectio maritalis ${ }^{9}$, não pode acarretar consequências jurídicas indesejadas aqueles que submetem a essa relação. Tornando-se incongruente consagrar a esse instituto o que se aplica na união estável, uma vez que sem a manifestação de ambos indivíduos dessa união em constituir família seria um retrocesso adotar ao caso concreto uma prescrição legal genérica (BRASIL, 2015a).

Nesse seguimento, faz-se indispensável respeitar a liberdade e a dignidade da pessoa humana para, como queiram, decidir o instituto familiar desejado, e, na omissão de consentimento, deve-se considerar a intenção pessoal daqueles que se unem (ALVES et al., 2016).

\footnotetext{
${ }_{9}$ Ânimo de constituir família (MALUF; MALUF; 2016).
} 
Com esse entendimento, sobre a autonomia dos que se relacionam, Costa (2007, p. 165166 , grifo nosso) aduz que

[...] a autonomia privada possibilita às partes determinar as diretrizes de sua vida pessoal, mas, de acordo com a nova cisão do direito, em nenhuma esfera esses mesmos indivíduos têm uma ilimitada possibilidade volitiva e de criação, pois a função social dos institutos não permite que isso aconteça. Nesse sentido, normas cogentes determinarão o conceito e os novos limites da autonomia da vontade. (COSTA, 2007, p. 165-166, grifo nosso).

Isabela Paranaguá norteia as diferenças entre as relações supramencionadas, explicando que

[...] a diferença entre o namoro qualificado e a união estável, que tratam sobre a vontade da constituição de família. O namoro qualificado é um relacionamento entre duas pessoas maduras, que convivem, pernoitam ou coabitam. Só que aí gera uma confusão, se aquilo em determinado momento da relação vai ser namoro ou união estável. Esse termo namoro qualificado vai ter os mesmos elementos objetivos que a união estável (essa que é pública, duradoura, notória), mas não tem elemento subjetivo, que é a vontade presente de constituir família. Na união estável essa vontade é presente. (PIAUILINO, 2015).

Visto isto, se o objetivo da união não for para constituir família no presente, sendo apenas um projeto de vida afetiva conjunta para o futuro, é necessário respeitar a escolha de ambos na forma de se relacionar, podendo caracterizar esse ideal perfeitamente como namoro qualificado (BRASIL, 2015a).

Nesse mesmo viés, o STJ, sobre a existência ou não de união estável entre um casal, trouxe reflexões e apontamentos ao caso discutido judicialmente que se mostrou como um meio de melhor entendimento para o tema em que se discute (BRASIL, 2015a).

Sobre o aludido julgamento, referente ao Recurso Especial n. ${ }^{\circ} 1.454 .643$ - RJ (2014/0067781-5), de relatoria do Ministro Marco Aurélio Bellizze, a $3^{\text {a }}$ Turma do STJ empreendeu séria análise do instituto do namoro qualificado em face da união estável, tendo o acórdão a seguinte ementa:

Recurso especial e recurso especial adesivo. ação de reconhecimento e dissolução de união estável, alegadamente compreendida nos dois anos anteriores ao casamento, c.c. partilha do imóvel adquirido nesse período. 1 . alegação de não comprovação do fato constitutivo do direito da autora. prequestionamento. ausência. 2. união estável. não configuração. namorados que, em virtude de contingências e interesses particulares (trabalho e estudo) no exterior, passaram a coabitar. estreitamento do relacionamento, culminando em noivado e, posteriormente, em casamento. 3. namoro qualificado. verificação. repercussão patrimonial. inexistência. 4. celebração de casamento, com eleição do regime da comunhão parcial de bens. termo a partir do qual os então namorados/noivos, maduros que eram, entenderam por bem consolidar, consciente e voluntariamente, a relação amorosa vivenciada, para constituir, efetivamente, um núcleo familiar, bem como comunicar o patrimônio haurido. observância. necessidade. 5. recurso especial provido, na parte conhecida; e recurso adesivo prejudicado. (BRASIL, 2015a). 
Nesta análise, para o Ministro relator da decisão não houve união estável, “[...] mas sim um namoro qualificado, em que, em virtude do estreitamento do relacionamento projetaram para o futuro - e não para o presente -, o propósito de constituir entidade familiar” (BRASIL, 2015a).

Continuou o Ministro Bellizze em seu voto no REsp em exame, mencionando que deve ser reconhecido, em verdade, o namoro qualificado, que muitas vezes tem "[...] como único traço distintivo da união estável, a ausência da intenção presente de constituir uma família. Quando muito há, nessa espécie de relacionamento amoroso, o planejamento, a projeção de, no futuro, constituir um núcleo familiar" (BRASIL, 2015a).

Consequentemente, a respeito do namoro simples, o Ministro Relator alegou (BRASIL, 2015a) que

[...] para que se configure o início do namoro, basta que duas pessoas iniciem um relacionamento amoroso, o que abrange desde encontros casuais até relacionamentos mais sérios, nos quais há publicidade, fidelidade e uma possível intenção de casamento ou constituição de união estável no futuro. A confusão que pode surgir entre o namoro e a união estável, no entanto, ocorre nas relações em que há observância das regras morais impostas pela sociedade. São aqueles relacionamentos duradouros, com convivência contínua do casal, nos quais há fidelidade mútua, pelo menos na aparência, na qual ambos se apresentam na sociedade como namorados. A doutrina divide o namoro em simples e qualificado. O namoro simples é facilmente diferenciado da união estável, pois não possui sequer um de seus requisitos básicos. (BRASIL, 2015a).

No que diz respeito ao namoro qualificado, também em seu voto, o Ministro consignou que

[...] o namoro qualificado apresenta a maioria dos requisitos também presentes na união estável. Trata-se, na prática, da relação amorosa e sexual madura, entre pessoas maiores e capazes, que, apesar de apreciarem a companhia uma da outra e, por vezes, até pernoitarem com seus namorados, não têm o objetivo de constituir família. Por esse motivo é tão difícil, na prática, encontrar as diferenças entre a união estável e o namoro qualificado. Muito embora as semelhanças existentes entre ambos, o que os diferencia é o objetivo precípuo de constituir família - presente na união estável e ausente no namoro qualificado. (BRASIL, 2015a, grifo nosso).

À vista desses argumentos, considera-se união estável a família constituída no momento atual de forma plena que transmite a imagem externa de um casamento. Em contrapartida, o namoro qualificado é um relacionamento em que os namorados meramente alimentam uma expectativa de constituição de uma família no futuro, desprovido de affectio maritalis (ALVES et al., 2016).

Carlos Alberto Dabus Maluf e Adriana Dabus Maluf, em seu Curso de Direito de Família, abordam o tema e aduzem que: 
[...] no namoro qualificado, por outro lado, embora possa existir um objetivo futuro de constituir família, não há ainda essa comunhão de vida. Apesar de se estabelecer uma convivência amorosa pública, contínua e duradoura, um dos namorados, ou os dois, ainda preserva sua vida pessoal e sua liberdade. Os seus interesses particulares não se confundem no presente, e a assistência moral e material recíproca não é totalmente irrestrita. (MALUF; MALUF, 2013, p. 371-374).

Sobre a união estável, entende Maluf (2010):

Pode-se, assim, concluir, que a família formada pela união estável, representa um fato natural e bastante presente na sociedade através dos tempos históricos, legitimada na realidade brasileira pela jurisprudência, por leis esparsas, até encontrar respaldo constitucional, rompendo assim com a injustiça, o casuísmo, o preconceito, permitindo que o homem inserido na tipologia de família que melhor lhe convier possa ter sua intrínseca dignidade valorizada, desenvolver os atributos inerentes à sua personalidade. (MALUF, 2010, p. 108).

Por conseguinte, é notável a diferenciação da união estável do namoro qualificado, vez que neste

[...] embora possa existir um objetivo futuro de constituir família, não há ainda essa comunhão de vida. Apesar de se estabelecer uma convivência amorosa 49 pública, contínua e duradoura, um dos namorados, ou os dois, ainda preserva sua vida pessoal e sua liberdade. Os seus interesses particulares não se confundem no presente, e a assistência moral e material recíproca não é totalmente irrestrita. (MALUF; MALUF, 2016, p. 9-10, grifo nosso).

Ademais, cumpre ressaltar que na união estável, diferentemente do namoro qualificado, faz-se "[...] absolutamente necessário que entre os conviventes, emoldurando sua relação de afeto, haja esse elemento espiritual, essa 'affectio maritalis', a deliberação, a vontade, a determinação, o propósito, enfim, o compromisso pessoal e mútuo de constituir família" (VELOSO apud BRASIL, 2015a).

Do mesmo modo, verifica-se que a jurisprudência também já enfrentava a distinção entre as duas modalidades de relacionamento, sob a proposição de que "[...] não se pode compreender como entidade familiar uma relação em que não se denota posse do estado de casado, qualquer comunhão de esforços, solidariedade, lealdade (conceito que abrange franqueza, consideração, sinceridade, informação e, sem dúvida, fidelidade)". (BRASIL, 2010).

É o que demostrou o julgamento do REsp de n. ${ }^{\circ} 1.157 .273$ - RN de relatoria da Ministra Nancy Andrighi, que proferiu o seguinte acórdão:

Civil e direito de família. apelação cível. ações de reconhecimento de união estável post mortem. casamento. divórcio. rompimento do vínculo matrimonial. restabelecimento da relação afetiva. configuração de uniões estáveis concomitantes. falecimento do companheiro. policial federal. direito ao recebimento da pensão por morte. rateio proporcional entre as companheiras. possibilidade. precedentes desta corte e do STJ. conhecimento e desprovimento da apelação (BRASIL, 2010). 
Dado isso, significativo registrar que para a constituição da união estável o casal, obrigatoriamente, tem que demonstrar a vontade eminente de constituir família no presente, de feitio que devem viver e se apresentar para a sociedade como se casados fossem. Ou seja, "significa dizer que deve haver assistência moral e material recíproca irrestrita, esforço conjunto para concretizar sonhos em comum, participação real nos problemas e desejos do outro, entre outros" (MALUF; MALUF, 2016, p. 9).

A respeito do namoro qualificado, ainda que o casal tenha o propósito futuro de constituir família, não existe a plena comunhão de vidas. Pois, apesar de se relacionarem de forma pública, contínua e duradora, o elemento subjetivo de constituir família, denominado affectio maritalis, não está presente na relação afetiva, à medida que um dos namorados ou até mesmo os dois mantém preservada sua vida individual e sua liberdade (BRASIL, 2015a).

Dessa feita, para que haja a união estável é necessária a notoriedade, a convivência more uxório e a constância das relações com o objetivo de constituir uma família, não configurando união estável os relacionamentos meramente afetuosos e sem objetivo de prolongamento no tempo ou mesmo os que buscam esse fim, mas que no presente tem apenas uma expectativa de constituir família.

Consequentemente, em vista dos argumentos apresentados, certifica-se que diante das mais variadas formas de se relacionar presentes na contemporaneidade, não se deve, de forma alguma, considerar sem examinar os elementos constitutivos de uma união afetiva, especialmente, o ânimo presente de constituir família, uma união afetiva como união estável, de maneira a acarretar pela negligência, uma interferência indireta por parte do Estado nas uniões em que se discute. Pois, ainda que as referidas uniões afetivas guardam similaridade tênue, na realidade, tais uniões devem ser interpretadas com base na real vontade dos que se relacionam, não apenas na imagem transmitida as pessoas do meio em que estes vivem.

Diante disso, ao vislumbrar-se da diferença entre a união estável e o namoro qualificado, que em linhas gerais, aquele se traduz na família já constituída no presente e este na união amorosa com mera perspectiva de constituir família no futuro, o Estado, através de sua função judicante, deve se ater as peculiaridades dessas uniões para depois qualifica-las. Salvaguardando, com isso, a imposição ilegítima de deveres, especialmente, os patrimoniais pela consequência jurídica da partilha de bens dentre outras, caso venha uma união a ser considerada equivocadamente como entidade familiar formada pela união estável. 


\subsection{O Reconhecimento do Namoro Qualificado Consoante o Ordenamento Jurídico}

\section{Brasileiro}

Como pôde-se aferir, a compreensão imprecisa de que uma relação amorosa que mantém superficialmente os elementos constitutivos de uma união estável não devem ser, dogmaticamente, entendidos como tal, em conformidade com atual conjectura das uniões correntes (MALUF; MALUF; 2013).

Ao passo que uma união caracterizada pelo namoro qualificado quando enquadrada desacertadamente como entidade familiar já formada, pode, sem qualquer tipo de dúvidas, acarretar consequências indesejadas e incongruentes com os preceitos constitucionais para aqueles que se relacionam afetivamente (ALVES et al., 2016).

Nesse sentido, como se sustentou neste trabalho, o Estado deve garantir aos amantes em uma relação sua fiel vontade, analisando sistematicamente no caso concreto a existência ou não do objetivo presente de se constituir família pela união estável. Assim sendo, não se busca a interferência do Estado na vida privada dos que se relacionam, mas sim, a proteção das consequências decorrentes da compreensão equivocada do namoro qualificado como união estável, ensejando, pela sistemática legal, os direitos decorrentes desta última pela aplicação do regime de comunhão parcial de bens ${ }^{10}$ (DINIZ, 2008).

Dessa maneira, esses reconhecimentos de direitos "somente geram responsabilidades e encargos os relacionamentos que, por sua duração, levam ao envolvimento de vidas a ponto de provocar verdadeira mescla de patrimônios" (DIAS, 2016, p. 171-172).

Salienta-se, por oportuno, que o estreitamento de uma relação amorosa, independentemente do seu intento para tanto, como se percebe em um noivado, aspirando uma constituição futura de família pode "[...] ocorrer a formação de sociedade de fato entre os noivos, sendo que neste caso não se detém qualquer tipo de contrato ou documento que estipule os direitos e obrigações dos sócios, nem tampouco os objetivos sociais da empresa, ou registro no órgão competente" (MALUF; MALUF, 2016, p. 17).

Isto posto, no que diz respeito ao namoro qualificado, pode-se, similarmente, compreender " [...] a configuração de sociedade de fato entre os noivos, com o objetivo de construção de um patrimônio comum, com vistas ao futuro casamento. Cria-se, deste modo, uma verdadeira sociedade de fato entre os noivos quando, confiantes um no outro, adquirem bens em nome apenas de um deles" (MALUF; MALUF, 2016, p. 17, grifo nosso).

\footnotetext{
${ }^{10}$ Como foi discutido neste trabalho, a entidade familiar formada pela união estável quando está desprovida de contrato que estabeleça o regime de bens a ser aplicado na relação dos conviventes, aplica-se o regime da comunhão parcial de bens, conferindo, entre outros direitos, a meação dos bens adquiridos onerosamente na constância da união (BRASIL,2002). Com efeito, como o namoro qualificado se assemelha com a referida família e, não dispõem, em regra, de nenhuma escritura na maioria dos casos, se tal relação for compreendida como união estável, por óbvio, aplicar-se-á as regras referentes a união estável (MALUF; MALUF, 2016).
} 
Por conseguinte, pontua-se plenamente cabível o reconhecimento de um namoro qualificado como uma sociedade de fato que, por sua vez, será regida pelas regras de Direito Obrigacional, pela comprovação de esforço comum para a aquisição de patrimônio na constância do namoro, respeitando, em cada caso específico, o contraditório e a ampla defesa para confirmação ou não da ajuda mútua que, porventura, pode ser alegada (FARIAS; ROSENVALD, 2017).

Observando, nessa lógica, o princípio da boa-fé, nos moldes do artigo 422 do Código Civil $^{11}$, para que se possa conferir, após comprovada a sociedade de fato pelos namorados em Juízo, a veracidade do que se alega como esforço comum para eventual partilha de patrimônio (FARIAS; ROSENVALD, 2017).

Além disso, deve-se atentar também, com a finalidade de se manter reconhecido o instituto afetivo formado por meio do namoro qualificado os preceitos trazidos pelo novo Código de Processo Civil, instituído pela Lei 13.105 e promulgado aos 16 dias de março de 2015, vigente desde março de 2016 (BRASIL, 2015a).

Pelo motivo de que, com a nova ordem processual "[...] os precedentes judiciais também vinculam as decisões judiciais atualmente, já que o novo CPC estabelece que não se considera fundamentada qualquer decisão judicial que deixar de seguir precedente ou jurisprudência invocada pela parte [...]" (FERNANDES, 2016, grifo nosso).

Essa questão é tratada pela redação do artigo $489, \S 1^{\circ}$, VI, do Código de Processo Civil, que preceitua que "[...] não se considera fundamentada qualquer decisão judicial [...] que [...] deixar de seguir enunciado de súmula, jurisprudência ou precedente invocado pela parte, sem demonstrar a existência de distinção no caso em julgamento ou a superação do entendimento" (BRASIL, 2015b).

Da mesma forma, o mesmo texto legal assevera que "os tribunais devem uniformizar sua jurisprudência e mantê-la estável, íntegra e coerente" (BRASIL, 2015b, grifo nosso), demonstrando claramente a necessidade de se respeitar as decisões proferidas pelos tribunais superiores, especialmente, pela uniformização do entendimento de determinado assunto já apreciado pelo Poder Judiciário nas vias extraordinárias.

Não bastasse a vasta imposição acima mencionada, o artigo 927, também do Código em que se alude, consigna-se que os Juízes e os Tribunais deverão sempre observar as decisões já analisadas e decididas (BRASIL, 2015b).

Essa sistemática adotada pelo Código de Processo Civil, pode ser melhor compreendida, de acordo com o posicionamento de Francis Ted Fernandes (2013), que dispõe de maneira clara que "[...] o capítulo seguinte de cada 'romance' deve necessariamente 'guardar correlação com o capítulo anterior'. Um rompimento total entre similaridade das decisões somente é possível,

\footnotetext{
${ }^{11}$ Art. 422. Os contratantes são obrigados a guardar, assim na conclusão do contrato, como em sua execução, os princípios de probidade e boa-fé (BRASIL, 2002).
} 
mediante uma carga de argumentação extrema que se justifique, com base nas peculiaridades do caso concreto.

À vista disso, sabido que o namoro qualificado já foi conhecido em sede de REsp pelo STJ e embasado nas diretrizes do Lei Processual Civil sobre a necessária observação dos precedentes, o instituto amoroso em análise deve, indubitavelmente, ser reconhecido no ordenamento jurídico brasileiro.

De maneira que como fora examinado nas disposições acima, considerando as individualidades de cada relação afetiva, precipuamente, quando da apreciação de um determinado caso específico pelo Poder Judiciário, os elementos caracterizadores da família formada pela união estável, merece séria atenção ao considerarmos as várias formas de relacionamentos amorosos presentes no contexto social nacional.

À medida que não se pode olvidar do elemento principal da família constituída pela união estável, ou seja, a vontade presente de constituir família, que, diferentemente da entidade familiar discriminada, não se faz presente na eminência do namoro, mas se perfaz como uma mera projeção futura de constituir família.

Nessa linha de entendimento, Viegas e Poli (2015, p. 95) preceituam que o direito “[...] é sistemático e aplicação da juridicidade impõe a interpretação teleológica de todo o ordenamento jurídico, devendo ser considerados, portanto, todos os princípios e regras que se amoldam à situação jurídica das novas famílias que vem surgindo na sociedade.”

Por isso, compreendem que "[...] o direito não pode fechar os olhos para os fatos sociais, mas, sim, enfrentá-los a fim de não legitimar desigualdades, enriquecimento ilícito, efetivando, com isso, a dignidade dos membros dos novos formatos de família que vem surgindo na sociedade" (VIEGAS; POLI, 2015, p. 96).

Sendo assim, frente todos os argumentos já apresentados, o Estado, por meio de sua função precípua de aplicação e interpretação da norma ao caso concreto, deve, necessariamente, considerar a existência do namoro qualificado para que, desse jeito, mantenha-se garantido todos os direitos daqueles que se relacionam de maneira mais consistente que o namoro simples.

De maneira a respeitar a vontade fidedigna dos que se relacionam e não impondo ou negligenciando, como ocorreu em todo o contexto histórico da família, a supremacia do interesse estatal sobre os indivíduos e, por conseguinte, qualificando tais relações taxativamente em uma dogmática exata na generalidade dos amplos modelos de uniões afetivas. 


\section{Conclusão}

À vista desse conjunto de ideias apresentadas, em uma ótica, verifica-se que as uniões afetivas passaram por constantes evoluções, especialmente, as constituídas como família, de modo que como se pôde constatar, tal instituição sempre sofreu influência direta do Estado demasiadamente ao definir qual relacionamento podia ser considerado como entidade familiar ou limitando a liberdade dos indivíduos que se envolviam efetivamente com outrem.

Por outro lado, sem embargos, vislumbra-se que a contemporaneidade se vê marcada pelas mais variadas formas de relacionamentos amorosos no contexto social brasileiro. Nitidamente oriundas da própria concepção humana sobre se relacionar com outro indivíduo sem, necessariamente, estabelecer uma união compreendida como família constituída, mesmo que haja um estreitamente de vidas entre os casais.

Assim, o avanço da concepção das diversas formas de se relacionar, tanto pelo Estado como pela sociedade, resultou em uma compreensão equivocada de que tais relacionamentos são conceituados como união estável, ao considerar equivocadamente presentes os elementos constitutivos dessa união nos namoros que se mostram mais próximos da referida entidade familiar.

Isto porque, como as uniões afetivas hodiernas muitas vezes se assemelham bastante com a união estável, por se apresentarem, superficialmente, como a aludida entidade familiar, vários relacionamentos afetivos têm sido considerados como família eminentemente constituída, quando, em verdade, consiste na mera projeção de constituir família.

Destarte, consoante a demonstração feita neste trabalho, o namoro qualificado, que guarda respeito com a mera expectativa futura dos que se relacionam afetivamente de constituir família e mantém no presente sua liberdade individual, é plenamente válido de acordo com o ordenamento jurídico e com o entendimento atual do corpo social, como solução ao entendimento equivocado em que o referido instituto consiste como união estável e, por consequência, deveria se aplicar as disposições relativas a esta modalidade de família a uma situação que não condiz com fiel vontade dos indivíduos que namoram.

Assim sendo, considerando a diferença dos relacionamentos formados pelo namoro qualificado e pela união estável, por mais singela que seja, não se deve permitir a imposição ilegítima de deveres aos amantes, sobremaneira, os patrimoniais, de qualquer forma e sem observar o fiel intuito do indivíduo que se encontra neste tipo de união, em razão de sua viciada compreensão como família já constituída.

Ademais, como suscitou-se nesta análise, sobre a relevância dos precedentes judiciais, consoante as disposições do Código de Processo Civil na aplicação do Direito subjetivo aos indivíduos, sabido que o namoro qualificado foi conhecido recentemente pelo STJ, os novos casos devem respeitar a mesma sistemática. Sendo assim, o Estado, na análise do caso concreto levado para sua apreciação, deve reconhecer essa nova modalidade de afeição amorosa e aplica- 
la nos pleitos levados a sua apreciação, garantindo, desde modo, a fiel vontade do indivíduo que se relaciona com outra pessoa em virtude dos avanços do entendimento social face às novas formas de uniões afetivas.

\section{Referências}

ALVES, Weverton Fernandes Bento et al. Namoro qualificado: análise do julgamento do recurso especial $n^{\circ} 1.454 .643$ - rj (2014/0067781-5) pelo Superior Tribunal de Justiça e sua real aplicação. Revista Sinapse Múltipla, Betim, v. 5, n. 2, 2016. Disponível em: http://periodicos.pucminas.br/index.php/sinapsemultipla/article/view/13543. Acesso em: 2 fev. 2020.

BRASIL. Conselho Nacional de Justiça. Resolução n. ${ }^{\circ}$ 167, de 07 de janeiro de 2013. Revoga a Resolução n. ${ }^{\circ}$ 40, de 14 de agosto de 2007. Atos Normativos, Brasília, 07 jan. 2013. Disponível em: http://www.cnj.jus.br/atos-normativos?documento=1661. Acesso em: 29 fev. 2020.

BRASIL. Conselho Nacional de Justiça. Resolução n. ${ }^{\circ}$ 40, de 14 de agosto de 2007. Dispõe sobre os procedimentos de reconhecimento de união estável no âmbito do Conselho Nacional de Justiça. Atos Normativos, Brasília, 14 ago. 2007. Disponível em: http://www.cnj.jus.br/atosnormativos?documento=182. Acesso em: 28 fev. 2020.

BRASIL. [Constituição (1988)]. Constituição da República Federativa do Brasil. Diário Oficial da União, Brasília, 5 de out. 1988. Disponível em: http://www.planalto.gov.br/ccivil_03/constituicao/constituicaocompilado.htm. Acesso em: 28 fev. 2020.

BRASIL. Decreto n. ${ }^{\circ} 3.048$ de 6 de maio de 1999. Aprova o Regulamento da Previdência Social, e dá outras providências. Diário Oficial da União, Brasília, 6 maio 1999. Disponível em: http://www.planalto.gov.br/ccivil_03/decreto/d3048.htm. Acesso em: 28 fev. 2020.

BRASIL. Lei n. ${ }^{\circ} 13.105$ de 16 de março de 2015. Código de Processo Civil. Diário Oficial da União, Brasília, 16 mar. 2015b. Disponível em: http://www.planalto.gov.br/ccivil_03/_ato20152020/2015/lei/113105.htm. Acesso em: 28 fev. 2020.

BRASIL. Lei n. ${ }^{\circ} 8.213$ de 24 de julho de 1991. Dispõe sobre os Planos de Benefícios da Previdência Social e dá outras providências. Diário Oficial da União, Brasília, 24 jul. 1991. Disponível em: http://www.planalto.gov.br/ccivil_03/leis/L8213cons.htm. Acesso em: 28 fev. 2020.

BRASIL. Lei $\mathrm{n}^{\circ} 10.406$ de 10 de janeiro de 2002. Institui o Código Civil. Diário Oficial da União, Brasília, 10 de jan. 2002. Disponível em: http://www.planalto.gov.br/ccivil_03/Leis/2002/L10406compilada.htm. Acesso em: 28 fev. 2020.

BRASIL. Superior Tribunal de Justiça. Recurso Especial n. ${ }^{\circ}$ 1157273/RN. Relatora: Ministra Nancy Andrighi - Terceira Turma. Revista Eletrônica de Jurisprudência, Brasília, 7 jun. $2010 . \quad$ Disponível em: https://ww2.stj.jus.br/processo/revista/documento/mediado/?componente=ITA\&sequencial=973 541\&num_registro=200901892230\&data $=20100607 \&$ formato=HTML/. Acesso em: 28 fev. 2020. 
BRASIL. Superior Tribunal de Justiça. Recurso Especial no 1.454.643 - RJ (2014/0067781-5). Relator: Márcio Aurélio Bellizze - Terceira Turma. Revista Eletrônica de Jurisprudência, Brasília, 03 mar. 2015a. Disponível em: https://ww2.stj.jus.br/processo/revista/inteiroteor/?num_registro=201400677815\&dt_publicacao $=10 / 03 / 2015$. Acesso em: 28 fev. 2020 .

BRASIL. Supremo Tribunal Federal. Julgamento afasta diferença entre cônjuge e companheiro para fim sucessório. Notícias STF, 10 maio 2017. Disponível em: $\mathrm{http} / /$ www.stf.jus.br/portal/cms/verNoticiaDetalhe.asp?idConteudo=342982. Acesso em: 28 fev. 2020.

BRASIL. Supremo Tribunal Federal. Supremo reconhece união homoafetiva. Notícias STF, 05 maio 2011. Disponível em: http://www.stf.jus.br/portal/cms /verNoticiaDetalhe.asp?idConteudo=178931. Acesso em: 28 fev. 2020.

BRASIL. Turma Nacional de Uniformização dos Juizados Especiais Federais. Súmula 63. Diário Oficial da União, Brasília, 23 ago. 2012. Disponível em: http://www.jf.jus.br/phpdoc/virtus/sumula.php?nsul=63. Acesso em: 03 mar. 2020.

CAROSSI, Eliane Goulart Martins. As relações familiares e o direito de família no século XXI. Revista Faculdade de Direito, Caxias do Sul. v. 12, 2003.

COULANGES, Fustel de. A cidade antiga. 2. ed. São Paulo: Editora Martin Claret, 2007 [1903?].

COSTA, Maria Aracy Menezes da. Namoro qualificado: a autonomia da vontade nas relações amorosas. In: SOUZA, Ivone Maria Candido Coelho de (org.). Direito de família, diversidade e multidisciplinariedade. Porto Alegre: IBDFam, 2007.

DIAS, Maria Berenice. Família, ética e afeto. Brasília: Consulex, 2004.

DIAS, Maria Berenice. Manual de direito das famílias. 4. ed. São Paulo: RT, 2007.

DIAS, Maria Berenice. Manual de direito das famílias. 5. ed. São Paulo: Revista dos Tribunais, 2016.

DINIZ, Maria Helena. Curso de direito civil brasileiro: Direito de Família. 23. ed. São Paulo: Saraiva, 2008.

FACHIN, Luiz Edson. Teoria crítica do direito civil. Rio de Janeiro: Renovar, 2003.

FARIAS, Cristiano Chaves de; ROSENVALD, Nelson. Curso de Direito Civil: direito das famílias. 9. ed. rev. e atual. Salvador: Editora JusPODIVM. 2017.

FERNANDES, Francis Ted. O sistema de precedentes do novo CPC, o dever de integridade e coerência e o livre convencimento do juiz. Migalhas, São Paulo, 11 nov. 2016. Disponível em: http://www.migalhas.com.br/dePeso/16,MI248774,81042-

$\mathrm{O}+$ sistema+de+precedentes + do + novo $+\mathrm{CPC}+\mathrm{o}+$ dever+de+integridade+e. Acesso em: 7 mar. 2020 .

FREITAS FILHO, Roberto; LIMA, Thalita Moraes. Metodologia de Análise de Decisões MAD. Universitas JUS, Brasília, n. 21, p. 1-17, jul./dez. 2010. Disponível em: https://www.publicacoesacademicas.uniceub.br/jus/article/download/1206/1149. Acesso em: 21 set. 2020. 
FUGIE, E. H. A união homossexual e a Constituição Federal. Revista Brasileira de Direito de

Família, Porto Alegre: Síntese, IBDFAM, out./dez. 2002. n. 15.

GOMES, Myrna Maria Rodrigues Neves. As novas entidades familiares: o caminho trilhado para um novo conceito. 51 f. 2009. Monografia (Graduação em Direito) - Faculdade de Ensino Superior da Paraíba. 2009.

GOMES, Orlando. Direito de Família. 14. ed. Rio de Janeiro: Forense, 2002.

INSTITUTO BRASILEIRO DE GEOGRAFIA E ESTATÍSTICA. Censo Demográfico 2010. Diário Oficial da União, Brasília, 4 nov. 2010. Disponível em: http://www.INSTITUTO BRASILEIRO DE GEOGRAFIA E ESTATÍSTICA.gov.br/home/estatistica/populacao/censo2010/resultados_dou/default_resultado s_dou.shtm. Acesso em: 22 jan. 2020.

KertzMAn, Ivan. Curso Prático de Direito Previdenciário. 15 ed. rev., amp. e atual. Brasília: JusPODIVM, 2017.

LEITE, Gisele. O Novo Direito de Família. Revista Brasileira de Direito de Família. Porto Alegre, v. 9, n. 49, p. 112-20, ago-set. 2008.

LÔBO, Paulo. Direito Civil: família. 2. ed. São Paulo: Saraiva, 2009.

MALUF, Adriana Caldas do Rego Freitas Dabus. Novas modalidades de família na pósmodernidade. São Paulo: Atlas, 2010.

MALUF, Carlos Alberto Dubas; MALUF, Adriana Caldas do Rego Freitas Dubas. Curso de Direito de Família. São Paulo: Saraiva, 2013.

MALUF, Carlos Alberto Dubas; MALUF, Adriana Caldas do Rego Freitas Dubas. A união estável e o namoro qualificado: uma diferenciação. São Paulo, 27 set. 2016. Disponível em: http://www.adfas.org.br/admin/upload/conteudo/27092016\%20CarlosAlbertoDabusMaluf.pdf. Acesso em: 5 mar. 2020.

PIAUILINO, Isabel. Advogada explica diferença entre namoro qualificado e união estável. Rádio Teresina FM, 31 ago. 2015. Disponível em: http://www.teresinafm.com.br/advogadaexplica-diferenca-entre-namoro-qualificado-e-uniao-estavel/. Acesso em: 5 abr. 2020.

RÁO, Vicente. O Direito e a vida dos direitos. 2. ed. São Paulo: Resenha Universitária, 1976.

RUSSO, José. As Sociedades Afetivas e Sua Evolução. Revista Brasileira de Direito de Família, Porto Alegre, v. 7, n. 32, out - nov. 2005.

VIEGAS, C. M. A. R.; POLI, L. M. O Reconhecimento da família Poliafetiva no Brasil: uma análise à luz dos princípios da dignidade humana, autonomia privada, pluralismo familiar e isonomia. Duc In Altum, v. 7, p. 55-100, 2015.

WALD, Arnoldo. O novo direito de família. 14. ed. São Paulo: Saraiva, 2002.

Artigo submetido: 2018-04-20

Reapresentado em: 2020-03-20

Aceito em: 2020-04-28 